\title{
Epilogue
}

\section{The Socialist Past Today}

As I have shown throughout my examination of the international cultural programs organized by Bulgaria's power elites, multilayered considerations were at play in this global cultural extravaganza. A permanent feature of the encounters between small Bulgaria and the world was the close interrelationship between local and global dynamics in the policies pursued by the communist regime. Domestic factors shaped international choices while the global context determined the local implementation of Bulgarian decisions, creating a lively cultural program blending Bulgarian and universal messages that was unique in late socialist Eastern Europe. The events examined here capture the spirit of late socialism when an uneasy compromise was achieved between the Eastern European regimes and their citizens. For Bulgaria, this was the time of normalized developed socialism when Zhivkov's regime seemed to be in full control. But the events also reflected the uneasy worldwide attempts during the 1970s to reconcile the contradictory forces of East-West reconciliation, the growing influence of the postcolonial world, and the spread of global interconnectivity. From the perspective of small Bulgaria, the 1970s was a time of both limitations and opportunities, as economic and political constraints associated with Soviet influence went hand in hand with new possibilities for advancing novel global partnerships in the Third World. As experienced from the margins of Europe, the 1970s was a decade of 
measured optimism, accompanied by persistent efforts to resolve the contradictions of the new "global condition."

Another key feature of these cultural programs was the constant attempt to reconcile ideological, national, international, cultural, and global factors, as the agendas of socialism, nationalism, internationalism, cultural dynamics, and global forces collided, competed, and compromised. The Bulgarian regime envisioned programs that emphasized its communist aspirations and commitment to socialist internationalism. At the same time, the events were supposed to capture the national spirit of the Bulgarian people and its unique role in history. Yet, the unpredictable nature of cultural contact and its global dynamics necessitated constant finetuning of the official cultural message. Thus, a peculiar program ensued, which juggled conflicting priorities to showcase the idea that small Bulgaria was a committed builder of communism and socialist internationalism while also being a good Balkan neighbor, an appreciated European partner, and an active global player.

The existence of slippage between culture, propaganda, public relations, and nation branding is one of the insights from studying these cultural contacts, because crafting the public image of any state is bound to reflect diverse considerations. The focus on high-quality, meaningful culture with a universal message was paramount in the shaping of these programs, whether Bulgaria was showcasing its decisive role as "one of the oldest states of Europe," promoting its standing as a "grand civilization" separate from the ancient Greeks and Romans, or emphasizing the ability of state socialism to support the "real arts" and their classical, humanist content. During this time, official culture flourished indeed: Bulgarians partook in a rich cultural life at home and were able to explore other parts of the world, albeit selectively and under the watchful eye of the state. Yet, the ideological function of the cultural front under developed socialism never disappeared. Cultural contacts served to boost the legitimacy of the Zhivkov regime domestically while advancing its reputation and policy agenda internationally. The "cultural opening" of late socialist Bulgaria resulted from the aspiration of communist elites to reinvent themselves, reinvigorate the socialist system, and participate more actively in global developments related to détente and the expansion of global interconnectivity.

Not least, official culture served as a strategy of nation branding that followed the slippery slope of cultural nationalism. The focus of these events was a supposedly refined version of "patriotism" promoted through the 1300 Years Bulgaria events, which put the unique fate of Bulgaria at the crossroads of civilizations at the center of the celebratory programs. Bulgaria was both ancient and modern: the resilience and ingenuity of the Bulgarian people in the past paved the way for the noble endeavors of 
today's modern nation. Yet here again, official culture came full circle back to ideology, because the aspiration for unity of the past, present, and future laid out the only possible future: marching toward the bright horizons of communism. It is not coincidental that the regime spoke about "culturalpropaganda work" even as it adjusted its rhetoric to emphasize culture or ideology according to context.

Public relations campaigns are at their heart attempts at self-fashioning that often leave a meaningful imprint. Bulgaria actively used "the advantages of smallness" to redefine its reputation as the Soviet master satellite by asserting an image of national uniqueness. While the assurance of the eternal Bulgarian-Soviet friendship never disappeared, and the country's political, economic, and military policy followed Soviet mandates, in the sphere of culture small Bulgaria showed independence by sidestepping orthodox state socialist historical interpretations and cultural cannons, which frequently put the Soviets on alert. In the capitalist West, the idea that Bulgaria's forefathers, the Thracians, Proto-Bulgarians, and Slavs, helped shape a common European history and identity was gaining momentum. The important role of public diplomacy was obvious in small Bulgaria's encounters with a number of big states in the developing world, such as India, Mexico, and Nigeria, where lively contacts developed not only in the realm of culture, but also in economic, scientific, and technical exchange. Soft power strategies led to tangible hard power outcomes.

In the end, our understanding of the 1970s is richer if we include the experiences of "peripheral" actors while our knowledge of late socialism is fuller if we place it in a global context. At the same time local and global, executed in the spirit of socialist internationalism yet also pursuing new transnational directions, Bulgarian cultural contacts followed the logic of late socialism while they also reflected global trends of the 1970s. During this time, a small state on the margins of Europe was able to craft and assert a public image through its investment in culture, demonstrating that cultural diplomacy allows actors on the margins to create legitimacy domestically, make impact regionally, and gain visibility globally.

There are several important long-term consequences of the cultural extravaganza of the 1970s, which spilled over into dynamics outside of the scope of this book. The 1300 Years Bulgaria campaign and the cultural programs associated with it successfully boosted the legitimacy of the communist regime in charge of the country: up until the mid- to late 1980s, a normalized society, brought together in a common national vision, continued to tolerate many aspects of developed socialism and rarely voiced public criticism. The growth of dissent and protest only occurred in Bulgaria in the late 1980 s when civic associations of an environmental nature gained visibility. 
This situation in turn influenced the nature of the Bulgarian democratic transition, as communist reformers staged a palace coup against Zhivkov on 10 November 1989 with Soviet approval, and many members of the old state and party bureaucracy maintained their influence and power. One way of doing so was through international knowledge and contacts cultivated during the late socialist period.

The nature of nationalism in Bulgaria also underwent critical shifts during the 1980s. The cultural nationalism that crystallized on the occasion of the 1300-year anniversary in 1981 went hand in hand with growing assimilationist pressures on Muslim and especially Turkish minorities. In 1981, schoolchildren in Bulgaria went to see the film The Glory of the Khan, which showed events associated the establishment of the Bulgarian state in 681. In 1988, they went to see Times of Violence, which focused on the Islamization of the Rhodope region and featured gory scenes of torture, rape, and killing by Muslims. The patriotic pathos of the 1300th anniversary paved the road for the "rebirth" campaign of forced assimilation in 1984 and the expulsion of the Bulgarian Turks during the "great excursion" in 1989, which demonstrates how cultural nationalism can easily become highjacked in the service of ethnic cleansing.

Finally, the international contacts developed under socialism have shaped Bulgaria's current standing in the world. One example comes from the reinvention of political elites, some of whom pursued spectacular international careers, such as Irina Bokova - the daughter of a prominent Politburo member-who served as the head of UNESCO between 2009 and 2017. Bulgarian international relations underwent a transformation after 1989: in the 1990s and first decade of the twenty-first century, the focus of the state's political identity was on the return to Europe in the context of democratization, NATO membership, and EU accession, and thus a reorientation to the West occurred. Yet, other global partnerships continued: the presence of Bulgarian medical personnel, engineers, architects, and other professionals throughout the world and the military deals of state-owned companies with partners in the Middle East, Africa, and India all have Cold War roots. Recently, Bulgarian scholars have started asking questions about the role of foreign students in Bulgaria and the presence of Bulgarian specialists in the world. The global contacts established under socialism resonate in today's globalized world where the search for alternative global connections outside of Europe and the West is emerging as important.

The cultural policies of late socialism continue to be debated in contemporary Bulgaria. Thirty years after the end of communism, many Bulgarians think about the late 1970 s as the time when culture mattered: supported by the state financially, culture was universally available at home while it 
boosted Bulgarian prestige in the world. Of course, any interpretation of this historical legacy is filtered through people's conflicting understandings of the socialist period. In memory wars related to the nature of Bulgarian communism, culture remains an important issue as it informs the very meaning of the state socialist project; here again, culture becomes a proxy for ideology, as in the Cold War. ${ }^{1}$ Today, Bulgarians reflect on the socialist period from the position of their personal fate during the postsocialist transition. Similarly to elsewhere in Eastern Europe, nostalgia has a powerful impact on how people remember the recent past. ${ }^{2}$ The issue of communist elites and their postsocialist reincarnation remains a contested matter.

Many Bulgarians are fascinated with the life and career of Liudmila Zhivkova, the daughter of communist dictator Todor Zhivkov, who made possible the country's cultural extravaganza. Her young age, interest in Eastern philosophies, eccentric attire, and colorful international career made her stand out. Her role in envisioning the International Assembly of Children in 1979 created fond memories for the children of developed socialism who came of age in the late 1980s and are today the builders of democracy and capitalism. Not least, the mysterious circumstances surrounding her death have led to speculation about Soviet complicity in her assassination. After 1989, a number of her associates-from her bodyguard and nurse to her personal friends and advisors-published memoirs about their time working with Zhivkova. Some of these works try to idealize her and disassociate her figure from the communist regime. ${ }^{3}$ Other close collaborators have even promoted a non-conformist image of her as a person "who undermined ideological limitations, iron curtains, and Berlin walls." ${ }^{4}$ Despite the critical work of historians, in popular thinking Zhivkova is often admired as an outlier from the system. Her spiritualism-including a close relationship with a clairvoyant, Baba Vanga—resonates among Bulgarians who after the fall of communism turned to psychics to predict their uncertain future. Her reputation as having initiated a "golden century" of Bulgarian culture, both domestically and internationally, remains her signature legacy. One post in the Facebook group "Memories from the People's Republic" described her as a remarkable woman whose "good and beautiful deeds cannot be erased or forgotten" because she "made Bulgaria famous worldwide."

Zhivkova's legacy continues to be contested. In 2012, her daughter, Evgeniia Zhivkova, commemorated the seventieth anniversary of her mother's birth with an exhibition at the Gallery for International Art. Zhivkova had envisioned this museum as she purchased foreign art for Bulgarian collections (prompting accusations of the misuse of funds and the prosecution of art dealers after her death). Many close associates_including the former 
minister of culture Georgi Iordanov and the former chairman of the Union of Bulgarian Artists Svetlin Rusev-appeared at the opening, giving the gathering the flavor of a reunion of "Liudmila's circle." The exhibition featured photographs of Zhivkova's meetings with international leaders and public figures, from Leonid Brezhnev and Fidel Castro to Jimmy Carter and Indira Gandhi, but also publishing magnate Robert Maxwell, British sculptor Henry Moore, and Russian-Indian artist Svetoslav Roerich. According to the organizers, despite the "contemporary political polarization" about Zhivkova, her leadership of the cultural sphere had created "a hope for change" during difficult times. The project of forging a public hagiography of the late socialist power elites was underway. ${ }^{6}$

Later that year, an international academic conference on "the Bulgarian cultural opening to the world" at the University of Sofia tried to give a scientific stamp to the anniversary. The conference featured talks by close associates of Zhivkova's while her daughter reflected on her mother's contributions. But observers noticed in the audience the socialist-era head of State Security's Cultural Section, Dimitar Ivanov, a sinister reminder that any cultural opening under socialism was closely watched by the gatekeepers of the regime. Loud protests erupted at the event, accusing the organizers of rehabilitating the recent past and glorifying the communist elites. Critics insisted that Zhivkova was not "the minister of culture" but the "minister of dictatorship" (the words culture and dictatorship—kultura and diktaturarhyme in Bulgarian). Exchanges in the press between historians of different political orientations debated the appropriateness of an event that idealized the doings of communist elites without nuancing the power dynamics involved in the process of "cultural opening."

Socialist-era culture continues to provide a platform to fight out political disagreements regarding public spaces. In the center of Sofia a crumbling monument inaugurated in 1981 to commemorate the 1300-year jubilee for many years split architects, urban planners, cultural experts, and politicians over its possible removal or repair. This monument was installed in close proximity to the National Palace of Culture, built to host the Twelfth Congress of the BKP and the 1300th anniversary celebrations. Designed by a noted Bulgarian sculptor, Valentin Starchev, the monument embraced Zhivkova's core idea for the 1300-year jubilee: to show the unity of past, present, and future in the historical development of Bulgaria. The structure featured three seven-meter-high figures - the medieval King Simeon portrayed as a warrior and a scholar; a version of the Pietà or the mourning mother; and a worker shown as the creator-as well as a number of inspirational quotations from revolutionaries and writers. This monument became controversial early on. 
Completed in eight months, its marble plaques began to fall shortly after its opening in 1981. Zhivkov expressed repeated displeasure with its modernist design. ${ }^{8}$ After 1989 , the monument fell into extreme disrepair; skateboarders and drug users utilized it, but the falling marble plaques compelled Sofia municipality to cordon it off to prevent a lethal incident.

Throughout the first decade of the twenty-first century various opinions in the press, public forums, and online discussions debated its removal and the reinstatement of the Fallen Soldier Memorial (built in 1934 and removed in 1981), its renovation, or its transformation into a modern outdoors facility featuring climbing walls and skateboarding ramps. ${ }^{9}$ In the summer of 2017, despite the protests of cultural figures and campaigns to raise funds for its renovation, the municipal authorities embarked on a month-long removal process, using heavy machinery to take down the solid concrete structure. In November 2017, a small part of the interwar memorial to soldiers fallen in

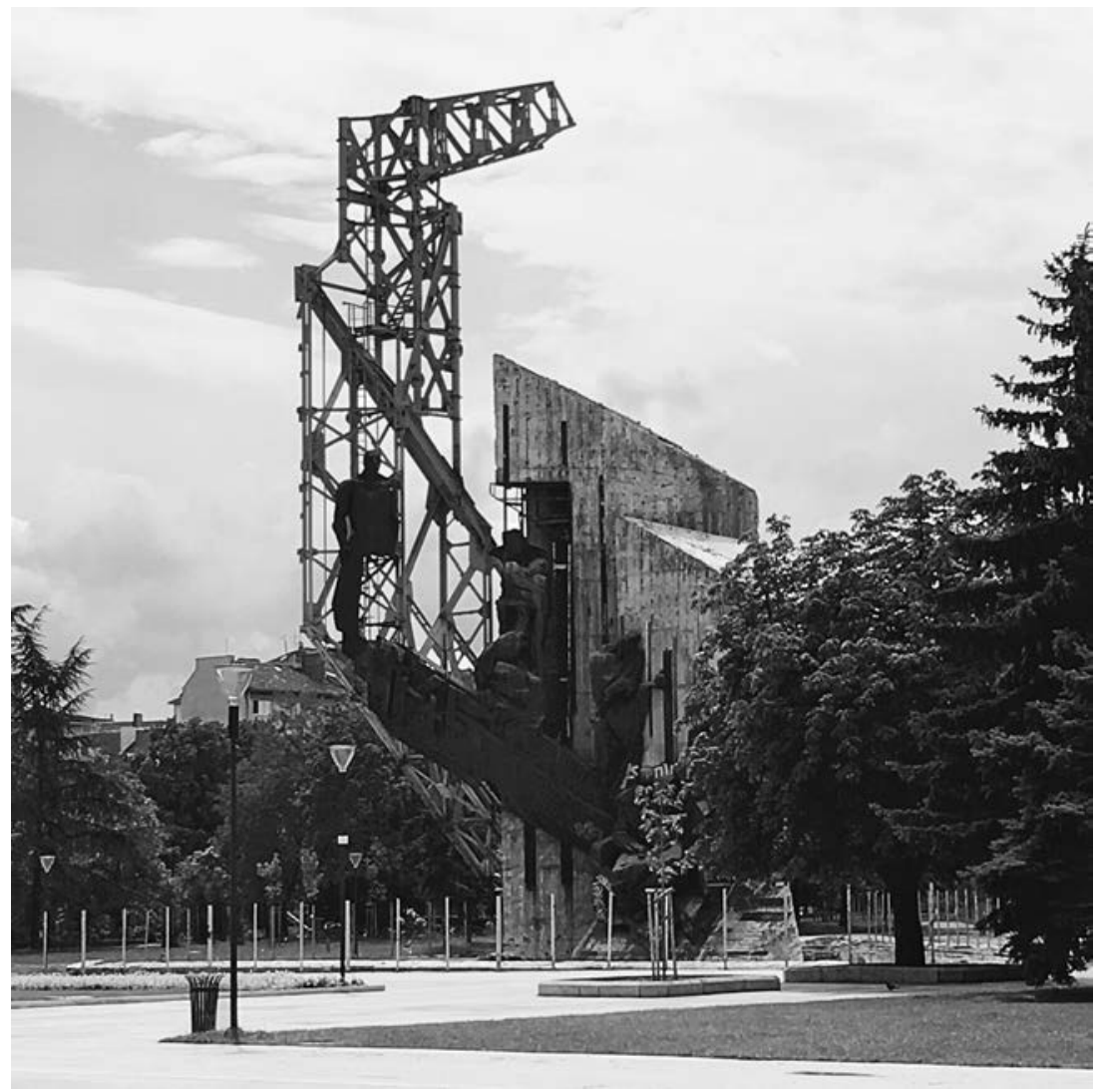

Figure 38. The 1300 Years Bulgaria Monument in ruins in 2016. Photo by author. 
the Balkan and First World Wars-a lion holding a shield picturing San Stefano Bulgaria-stood in the middle of a small garden, awaiting the full reconstruction of the monument. ${ }^{10}$ Postsocialist anticommunism had defeated socialist-era cultural nationalism by resurrecting an explicitly irredentist monument from the interwar years.

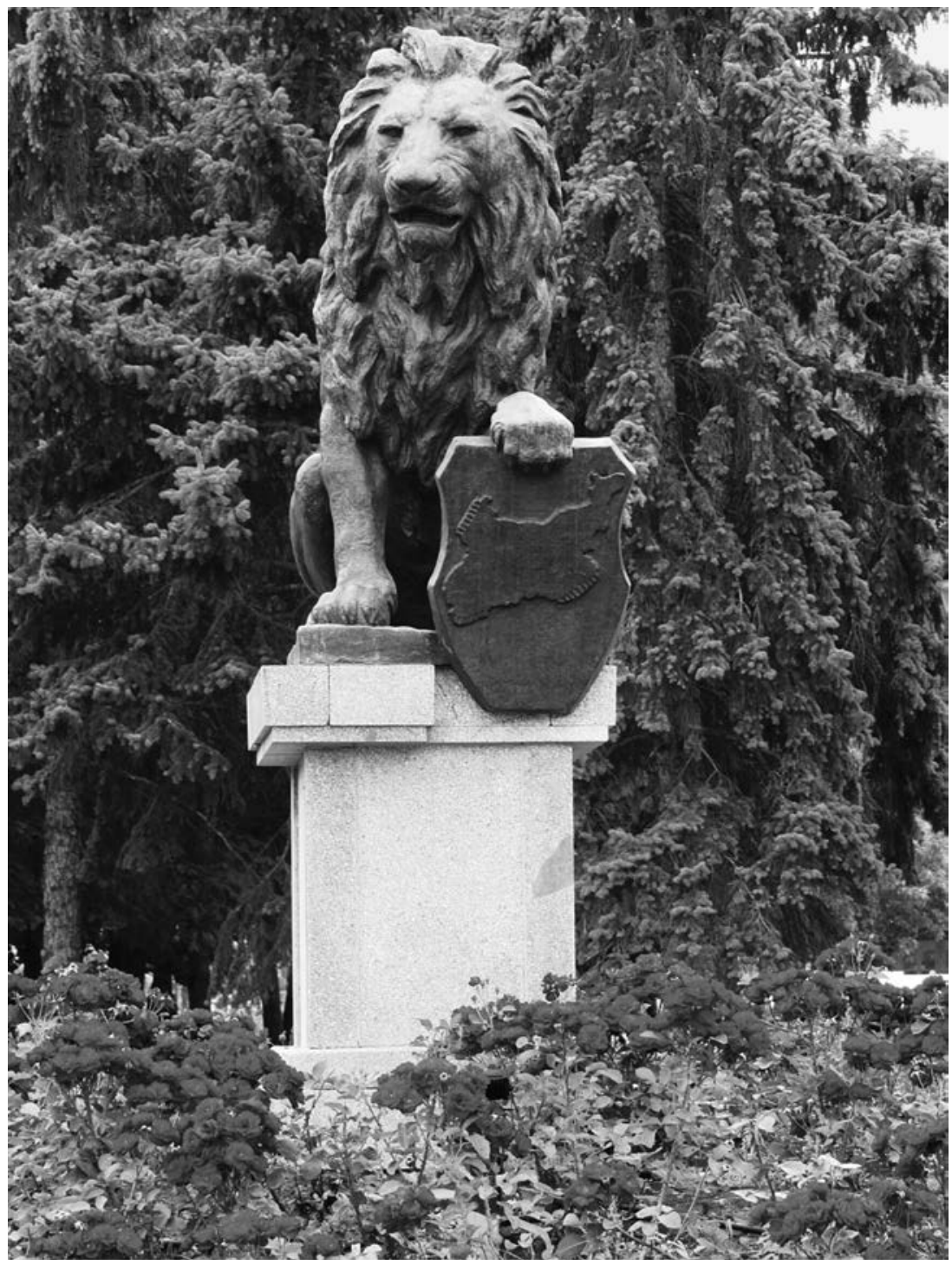

FigURE 39. The lion of the Fallen Soldier Memorial, installed in 2017 after the removal of the 1300 Years Bulgaria Monument. Photo by author. 
Heated debates surround other socialist-era monuments, notably the Home Monument of the Party on Buzludzha, built on top of the Balkan Mountains to commemorate the ninetieth anniversary of the BKP, also in 1981. In the 1990s, this monument similarly experienced disrepair and was closed to the public because water leaks damaged the ceiling while vandals destroyed its mosaics and glasswork. The eerie structure has attracted journalists and thrill-seekers worldwide who enter the monument illegally with the help of local guides. ${ }^{11}$ In summer 2019, a steady trickle of domestic and international tourists came to the summit (which also reveals breathtaking views) where the presence of an around-the-clock guard sought to discourage further scaling of the monument whose ceiling had started to collapse. That same year, Bulgarian and German architects won a Getty Foundation grant to design a conservation management plan to preserve the building "as an integral part of Bulgarian history" and explore options for the adaptive reuse of this "masterpiece of architectural engineering." ${ }^{\prime 2}$ This fascination with the Home Monument of the Party highlights a tortuous logic regarding historical preservation, which allowed the demolition of a socialist-era monument-1300 Years Bulgaria in Sofia-that honored national history using modernist visual tropes, yet seeks to preserve a monument celebrating the deeds of the BKP in the ideological language of Marxism-Leninism.

Cultural debates within Bulgaria have international dimensions, too. In April 2015, an exhibition of Thracian archaeological artifacts from Bulgaria opened at the Louvre. The prime minister, minister of culture, and a flock of journalists were present for the ceremony in Paris, provoking unflattering comparisons in the press with the state management of culture in the $1970 \mathrm{~s}^{13}$ There were heated discussions about the communist past when Prime Minister Boyko Borisov, a former bodyguard of Todor Zhivkov's, called the exhibition "a fulfillment of Liudmila Zhivkova's dreams." ${ }^{14}$ The fate of Thracian treasures has been a sensitive topic for many Bulgarians because the longtime director of the National History Museum, Bozhidar Dimitrov, seemed to have cozy relations with oligarchs who mysteriously acquired spectacular Thracian artifacts for their private collections. Accusations emerged that by showing these treasures at the Louvre, Dimitrov had helped them legalize their shady deals. But Dimitrov's position remained unapologetic while the media discussions of the Louvre exhibit provided publicity for his new book-a publication of his state security file together with a short biographical exposé bragging about his involvement in sexual escapades and Vatican political intrigues while working as a "cultural spy" in Italian museums and libraries in the 1970s. ${ }^{15}$

The cultural legacy of socialism was on display again in May 2015 when the prime minister inaugurated a new museum complex, Square 500, in the 


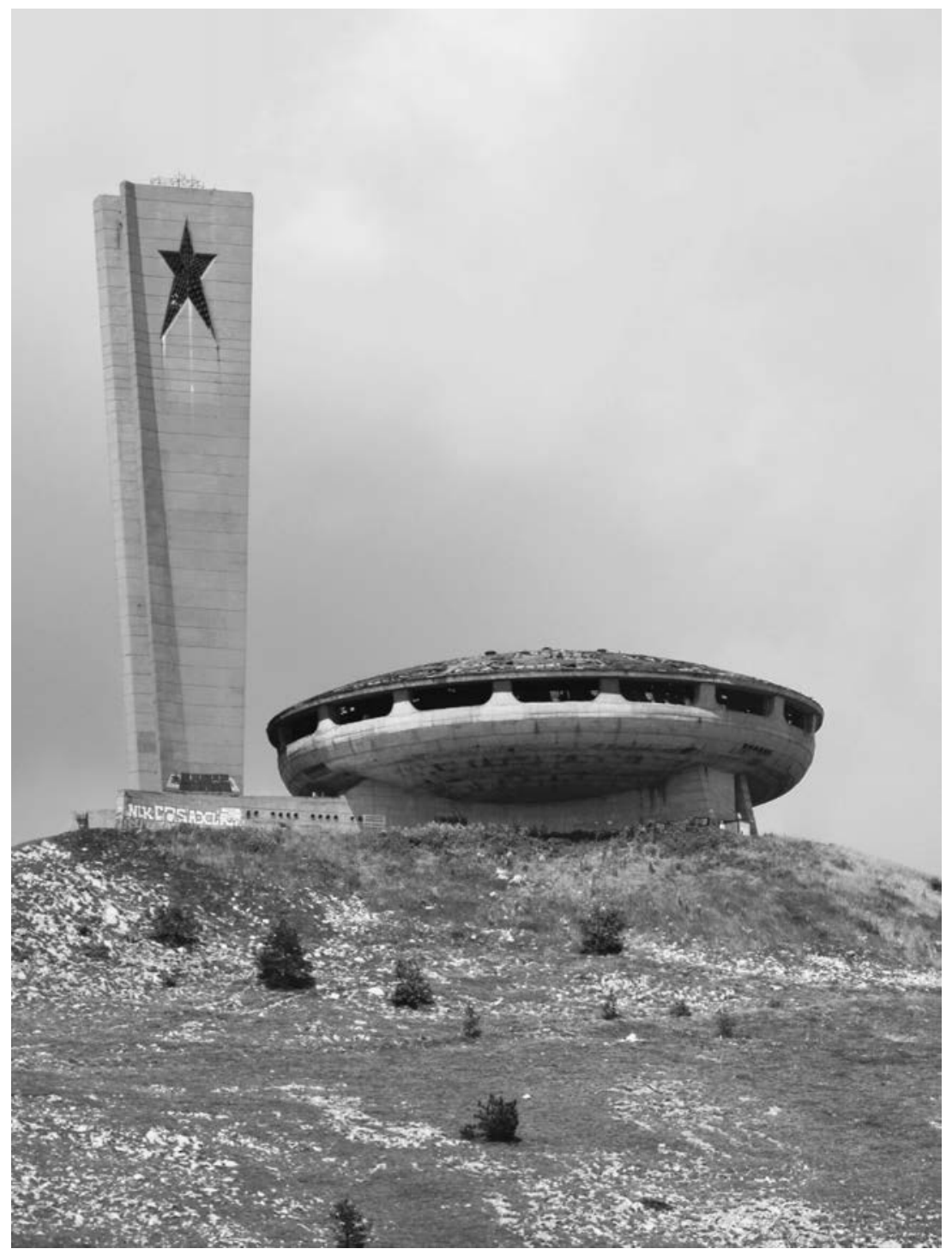

Figure 40. The Home Monument of the Party on Buzludzha in summer 2019. The graffiti, damaged ceiling, and missing red star are visible even from a distance. Photo by author.

building of the former Gallery for International Art. This building had first opened in 1985 to showcase the cultural endeavors initiated by Zhivkova. At the time, it represented the first systematic showing of foreign art. ${ }^{16}$ The current museum features an eclectic collection of Bulgarian, European, and world art. Notably, it houses numerous works of Russian-Indian artist 
Nicholas Roerich (the first "multifaceted personality" celebrated in 1978) donated by his son as well as extensive collections of ancient Indian, classic Japanese, African, and Central and Latin American art assembled under Zhivkova's patronage. Its chief curator was the aforementioned Svetlin Rusev, one of Zhivkova's closest associates, who had been instrumental in the efforts to promote her image as a cultural innovator. He single-handedly oversaw the arrangement of the exposition that featured some 42,000 artifacts and unapologetically defended the choices he made in his conception of it—or the lack of conception, as art experts have charged. ${ }^{17}$ Despite the conflicting opinions regarding this cultural investment during times of precarity, a familiar refrain dominated discussions on the "Bulgarian Louvre": culture is a good strategy for a small state to showcase its accomplishments to a global audience.

The tension between political, national, cultural, and international factors continues to define Bulgaria's cultural programs today. Political debates related to the communist legacy result in split opinions. Yet, public space is witnessing the remarkable embrace of an allegedly organic Bulgarianness, including omnipresent historical monuments and national symbols as well as official celebrations of the glorious past and popular fascination with allegedly authentic rites, traditional costumes, and folk traditions. A specter from the socialist past is haunting postsocialist Bulgaria: under the democratic political order, cultural nationalism is successfully building a social consensus on the unique historical destiny of small Bulgaria at the crossroads of civilizations. 